\title{
The effect of monosaccharide sugars and pyruvate on the differentiation and metabolism of sheep granulosa cells in vitro
}

\author{
B K Campbell, V Onions, N R Kendall, L Guo and R J Scaramuzzi ${ }^{1}$ \\ Division of Human Development, School of Clinical Sciences, University of Nottingham, Q.M.C., Nottingham \\ NG7 2UH, UK and ${ }^{1}$ Department of Veterinary Basic Sciences, The Royal Veterinary College, Hawkshead Lane, \\ Herts AL9 7TA, UK
}

Correspondence should be addressed to B K Campbell; Email: bruce.campbell@nottingham.ac.uk

N R Kendall is now at School of Veterinary Medicine and Science, University of Nottingham, Sutton Bonington Campus, Loughborough LE12 5RD, UK

\begin{abstract}
The objective of this study was to investigate the effect of three monosaccharides or pyruvate on the ability of gonadotrophins to induce cellular proliferation and differentiation of cultured sheep granulosa cells. Lactate production and levels of mRNA expression for the glucose transporters SLC2A1, SLC2A4, SLC2A5 and SLC2A8 were also determined. No energy source in the culture media reduced cell number $(50 \%)$ and oestradiol $\left(E_{2}\right)$ production. Dose and type of monosaccharide had a highly significant $(P<0.001)$ effect on FSHinduced differentiation of the granulosa cells, and there was a highly significant interaction $(P<0.001)$. Glucose supported higher levels of $E_{2}$ production than fructose, which was in turn higher than galactose $(P<0.001)$. In contrast, pyruvate at low doses supported similar levels of $E_{2}$ production as glucose, but higher doses were markedly inhibitory to $E_{2}$ production $(P<0.001)$. Cells responded positively to insulin $(P<0.001)$ in the presence of all three monosaccharides. Glucose and the high doses of fructose resulted in the accumulation of lactate $(P<0.001)$, but pyruvate, galactose and the low dose of fructose resulted in low lactate production. SLC2A5 expression was not detected and SLC2A8 expression was not affected, but SLC2A1 and SLC2A4 expression was depressed $(P<0.05)$ by culture in the presence of fructose and glucose. These data show that glucose, metabolised under anoxic conditions to lactate, is the preferred energy substrate to support the gonadotrophin-induced differentiation of ovine granulosa cells in vitro, and that fructose and pyruvate, but not galactose, are alternative energy substrates despite marked differences in the way these substrates are metabolised.

Reproduction (2010) $\mathbf{1 4 0} 541-550$
\end{abstract}

\section{Introduction}

In mammalian species, ovulation rate is determined by the number of follicles selected from the ovulatory wave of follicles, which in turn is controlled primarily by the levels and actions of key reproductive hormones (Webb \& Campbell 2007). Although ovulation rate is influenced by genetically determined factors, it is also influenced by environmental factors such as nutrition; and ovulation rates can adapt to align with nutritional status. Extreme energy restriction can lead to suppressed development of ovulatory follicles and anoestrus through inhibition of GNRH pulsatility (Jolly et al. 1995, McShane et al. 1994, Katz \& Vollenhoven 2000). However, increasing energy supply over a maintenance level leads to an increase in fecundity by an effect on follicle development and ovulation, which appears to act through a variety of mechanisms at both central and local levels (Scaramuzzi et al. 2006).

Glucose is a critical energy providing substrate for many cellular processes through its catabolism to produce ATP. Much of the current research suggests an indirect effect of glucose on ovarian function via nutritionally induced metabolic hormones such as insulin, insulin-like growth factor 1 (IGF1) and leptin (Peluso et al. 1984, Davis et al. 1990, Munoz-Gutierrez et al. 2002, 2004, 2005). Conversely, glucose may also act directly on the ovary. Evidence of glucose transporter expression (SLC2A1 and SLC2A4) on granulosa and theca cells of ovine antral follicles (Williams et al. 2001) and ovarian arteriovenous difference studies both suggest that significant amounts of glucose can be taken up by the ovary (Rabiee et al. 1997). In addition, glucose infused in combination with insulin into the ovarian artery of ewes with ovarian autotransplants directly suppressed androstenedione and oestradiol $\left(\mathrm{E}_{2}\right)$ production from the dominant follicle without affecting peripheral gonadotrophin concentrations (Downing et al. 1999).

Many foods contain other monosaccharides in addition to glucose, which may also mediate nutritional 
effects on follicular function. The supplementation of diets with lupins, which are high in galactose (van Barneveld 1999), stimulated folliculogenesis and increased fecundity in ewes (Knight et al. 1975). Enzymes involved in the metabolism of galactose are abundantly and actively expressed in the ovary, implicating it as a site of uptake, metabolism and utilisation (Heidenreich et al. 1993). Furthermore, significant plasma-follicular fluid concentration gradients in the human preovulatory follicle also suggest that galactose is both taken up and directly metabolised by ovarian follicles (Jozwik et al. 2007).

Along with glucose and galactose, fructose is a physiologically significant monosaccharide, particularly in human nutrition (Elliott et al. 2002), and is also the predominant blood sugar in foetal ruminants (Daniels et al. 1974). Fructose is absorbed via a fructose-specific member of the solute carrier family, SLC2A5 (formerly GLUT5), which is expressed mainly in the small intestines and testes (Burant et al. 1992). Fructose is an important energy substrate within the testis, being taken up from the seminal fluid and utilised by the mature spermatid as its main source of metabolic energy (Burant et al. 1992). Conversely, there is currently little evidence for a direct effect of fructose on the ovary. In one study, SLC2A5 mRNA expression was not detected in the rat ovary (Kol et al. 1997), and in the ruminant, fructose is thought to be rapidly metabolised to glucose in the liver (Luick et al. 1957) which may then trigger insulin release. In the primate and the human, fructose has little effect on insulin and leptin release or on the concentrations of blood glucose (Curry 1989, Havel 1997, Teff et al. 2004), but in sheep, we have observed increased insulin secretion in response to a challenge with fructose that differs in terms of duration and magnitude to challenges with identical doses of glucose (Onions et al. 2009). Furthermore, both direct ovarian and systemic infusions of fructose were observed to have an effect on ovarian steroidogenesis (Onions et al. 2009).

In summary, in addition to glucose, there is evidence to suggest that other monosaccharides such as galactose and fructose may also have effects on the ovary, which could mediate important changes in follicular development. Therefore, the objective of this study was to investigate the effect of dose and type of monosaccharide on the ability of gonadotrophins to induce cellular proliferation and differentiation of cultured granulosa cells in sheep.

\section{Results}

\section{Effect of dose and type of monosaccharide on $E_{2}$ production and cell number}

The first set of experiments examined the effect of dose and type of monosaccharide on cell number and $E_{2}$ production by cells cultured in the presence of a
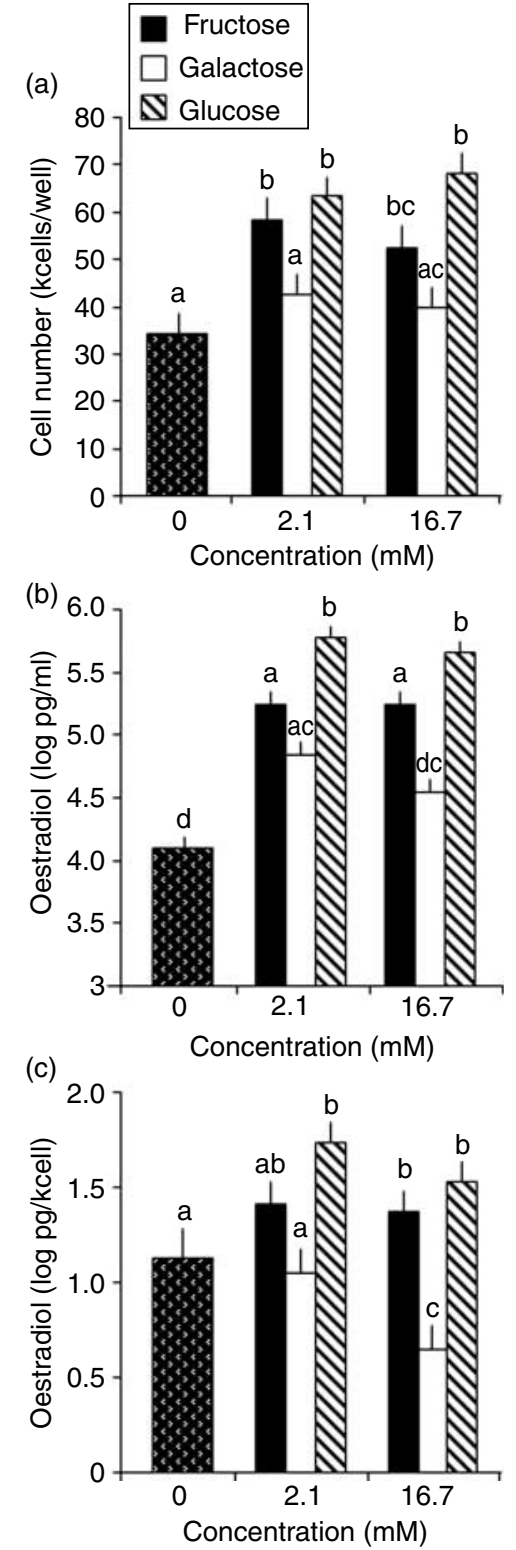

Figure 1 The effect of culturing ovine granulosa cells from small immature follicles (between 1 and $3 \mathrm{~mm}$ in diameter) under conditions known to induce cellular differentiation with increasing doses of three different monosaccharides on (a) cell number, (b) oestradiol production and (c) oestradiol production corrected for cell number after $192 \mathrm{~h}$ of culture. For clarity, only results from the physiological $(2.1 \mathrm{mM})$ and superphysiological (16.7 $\mathrm{mM}$ ) doses of monosaccharide have been included in this figure. Values are mean \pm s.E.M. Different letters indicate statistically significant differences $(P<0.05)$.

physiological dose of insulin $(10 \mathrm{ng} / \mathrm{ml})$. Absence of monosaccharide in the culture media resulted in around a $50 \%$ suppression in the number of viable cells after $192 \mathrm{~h}$ of culture $(P<0.001$; Fig. 1a) and correspondingly low levels of $E_{2}$ production (Fig. 1b, c). Regardless of dose or type of monosaccharide, hormone production by granulosa cells from small follicles exposed to low doses of FSH exhibited a standard steroidogenic induction 
profile (Campbell et al. 1996), characterised by a highly significant increase in $\mathrm{E}_{2}(P<0.001)$ production with time in culture peaking at $192 \mathrm{~h}$ (see for example Fig. 2). Dose and type of monosaccharide, however, had a highly significant effect on the characteristics of this response $(P<0.001)$, and there was a highly significant interaction between these two parameters $(P<0.001)$. Over all doses, glucose $(5.5 \pm 0.07 \mathrm{log} \mathrm{pg} / \mathrm{ml})$ resulted in significantly higher levels of $E_{2}$ production than fructose $(5.0 \pm 0.07 \mathrm{log} \mathrm{pg} / \mathrm{ml} ; P<0.001)$, which in turn was higher than galactose $(4.8 \pm 0.08 \mathrm{log} \mathrm{pg} / \mathrm{ml} ; P<0.01)$. Surprisingly, there was no significant difference in $E_{2}$ production at $192 \mathrm{~h}$ between low $(2.1 \mathrm{mM})$ and high (16.7 mM) doses of each monosaccharide (Fig. 1b), although the high dose of galactose resulted in a significant depression $(P<0.01)$ relative to both fructose and glucose (Fig. 1b). Examination of the effect of dose and type of monosaccharide on cell number after $192 \mathrm{~h}$ of culture revealed similar trends to those observed for $\mathrm{E}_{2}$ production with highly significant effects of dose and type of monosaccharide and a highly significant interaction $(P<0.001)$. Thus, glucose resulted in the highest cell numbers with levels around $80 \%$ of the initial plating density $(60 \pm 2.6 \mathrm{kcells} /$ well) with again no effect of dose of glucose over a large range of concentrations (Fig. 1a). Cell survival in the presence of fructose $(54 \pm 2.5 \mathrm{kcells} /$ well; $P<0.05)$ was slightly lower than that observed for glucose but was much lower in the presence of galactose $(38 \pm 2.2 \mathrm{kcells} /$ well; $P<0.01$ ). There were no differences in cell number within monosaccharides between the low or high doses

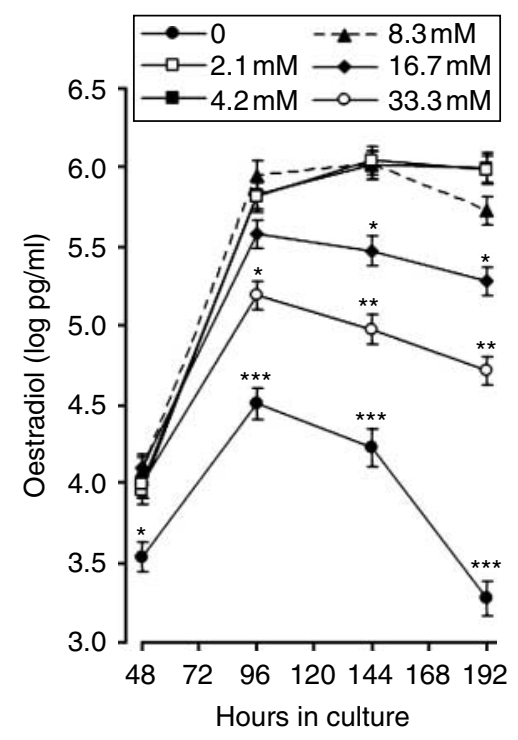

Figure 2 The effect of increasing doses of pyruvate on the induction of oestradiol production by granulosa cells from small immature follicles (between 1 and $3 \mathrm{~mm}$ in diameter) cultured for 48, 96, 144 and $192 \mathrm{~h}$. Cells were also cultured in the presence of $1 \mathrm{ng} / \mathrm{ml} \mathrm{FSH}, 10 \mathrm{ng} / \mathrm{ml}$ insulin and $10 \mathrm{ng} / \mathrm{ml}$ LR3-IGF1. Values are mean \pm s.E.M. Asterisks indicate statistically significant differences $(P<0.05)$. tested (Fig. 1a; $P>0.05$ ). When $E_{2}$ production was corrected for cell number (Fig. 1C), there were still highly significant effects of dose and type of monosaccharide and a highly significant interaction $(P<0.001)$. The main trends from this analysis were that $E_{2}$ production from cells cultured across all doses of glucose $(1.62 \pm 0.09 \log$ $\mathrm{pg} / \mathrm{kcell})$ was significantly higher $(P<0.001)$ than those cultured in the presence of galactose $(1.34 \pm 0.10 \mathrm{log}$ $\mathrm{pg} / \mathrm{kcell})$ or fructose $(1.30 \pm 0.08 \mathrm{log} \mathrm{pg} / \mathrm{kcell})$, which did not differ. In contrast, while there was no difference between high and low doses of glucose and fructose, the high dose of galactose $(16.7 \mathrm{mM})$ induced a significant inhibitory effect on $E_{2}$ production per cell relative to the low dose of this sugar (Fig. 1c; $P<0.05$ ).

\section{Effect of dose and type of monosaccharide in relation to insulin on $E_{2}$ production}

Insulin controls the utilisation and metabolism of monosaccharides and therefore, the next series of experiments examined the effect of the dose of insulin on granulosa cell differentiation at three doses of each of the three monosaccharides. The results of this analysis showed highly significant effects of insulin, the type and dose of monosaccharide, and the interactions among these three parameters (all $P<0.001$ ) on $\mathrm{FSH}$-mediated induction of $E_{2}$ production (Fig. 3). In the absence of monosaccharide, the dose of insulin had no significant effect on $E_{2}$ production, but in the presence of each monosaccharide, insulin induced a highly significant $(P<0.001)$ increase in $\mathrm{E}_{2}$ production. In line with our previous experimental series, the individual monosaccharides differed significantly in their ability to support the induction of $E_{2}$ production $(P<0.001)$ with glucose $(5.12 \pm 0.10 \mathrm{log} \mathrm{pg} / \mathrm{ml})$ being more potent than fructose $(4.62 \pm 0.09 \mathrm{log} \mathrm{pg} / \mathrm{ml})$, which in turn was more potent than galactose $(3.94 \pm 0.16 \mathrm{log} \mathrm{pg} / \mathrm{ml})$. Similarly, $\mathrm{E}_{2}$ production was not significantly different between low $(2.1 \mathrm{mM})$ and high $(16.7 \mathrm{mM})$ doses of glucose (Fig. 3c) and fructose (Fig. 3a), whereas the high dose of galactose was inhibitory compared to the low dose of galactose (both $P<0.05$ ) at the zero and $100 \mathrm{ng} / \mathrm{ml}$ doses of insulin (Fig. 3b).

In comparison, in this experiment, type of monosaccharide had no significant effect on cell number, and while highly significant $(P<0.001)$ effects of dose of monosaccharide and dose of insulin were observed on overall cell number, these differences were due primarily to low cell numbers at low doses of sugar and insulin, so that cell number was not affected by insulin for doses $>1 \mathrm{ng} / \mathrm{ml}$ (data not shown). Accordingly, analysis of the $E_{2}$ production data corrected for cell number resulted in the same main effects with very highly significant $(P<0.001)$ differences for type of monosaccharide, dose of monosaccharide and dose of insulin (data not shown). 

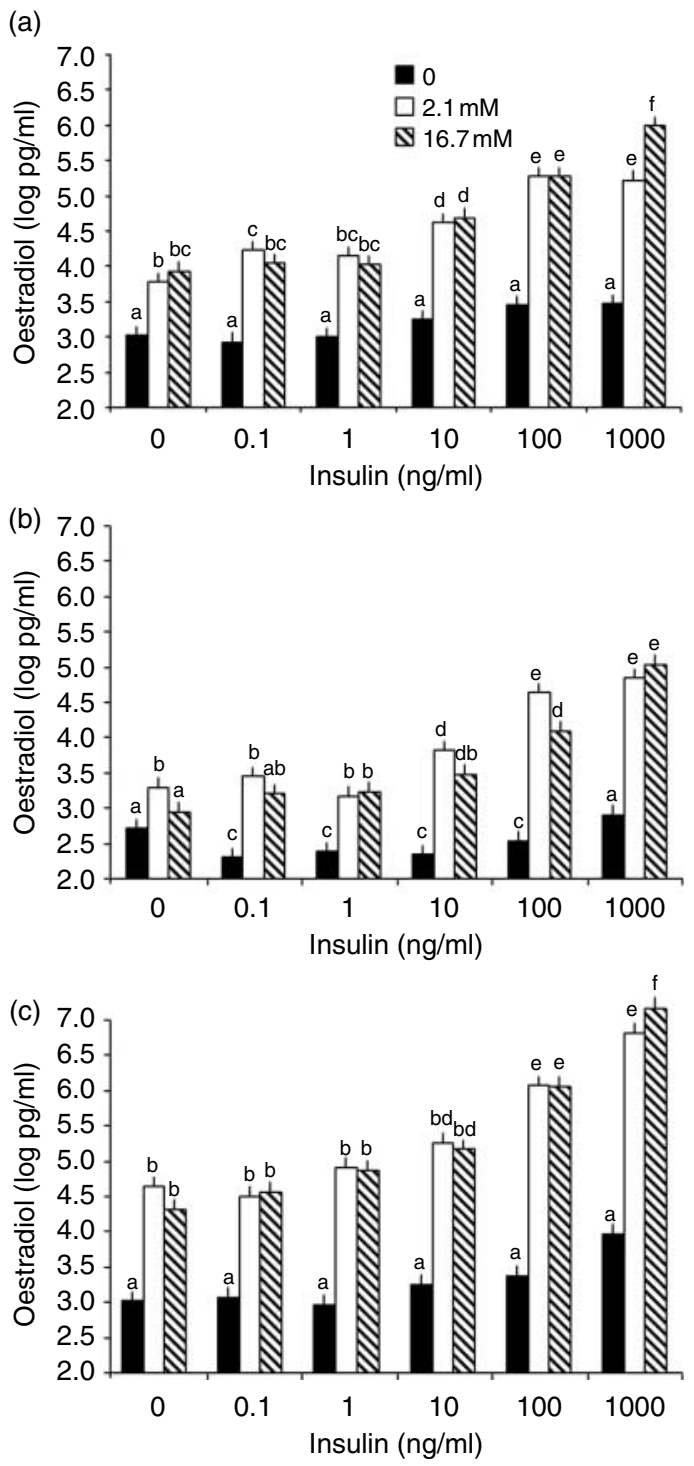

Figure 3 The effect of increasing doses of insulin on oestradiol production by granulosa cells from small immature follicles (between 1 and $3 \mathrm{~mm}$ in diameter) cultured for $192 \mathrm{~h}$ in the absence of, or in the presence of, physiological $(2.1 \mathrm{mM})$ or super-physiological $(16.7 \mathrm{mM})$ doses of (a) fructose, (b) galactose or (c) glucose. Cells were also cultured in the presence of $1 \mathrm{ng} / \mathrm{ml} \mathrm{FSH}$ and $1 \mathrm{ng} / \mathrm{ml}$ LR3-IGF1. Values are mean \pm s.E.M. Different letters indicate statistically significant differences $(P<0.05)$.

\section{Effect of pyruvate on granulosa cell differentiation}

Pyruvate is one of the major products of glycolysis, and thus represents the most likely intermediate energy source following monosaccharide metabolism. This series of experiments, therefore, examined the effect of increasing doses of pyruvate on the induction profiles of $E_{2}$ production. The results of these studies are presented in Fig. 2. Dose of pyruvate had a highly significant effect on $E_{2}$ production, and there was a highly significant interaction with time of culture $(P<0.001)$. Thus, lower doses of pyruvate resulted in classic induction profiles with a low initial concentration in the first $48 \mathrm{~h}$ of culture followed by a rapid increase at $96 \mathrm{~h}$, which remained elevated and stable after 144 and $192 \mathrm{~h}$ of culture (Fig. 2). In contrast, with doses of pyruvate above $8.3 \mathrm{mM}$, there were significant depressions in the production of $\mathrm{E}_{2}$ with the maximum level of production being reached after $96 \mathrm{~h}$ and falling progressively thereafter (Fig. 2). The maximum levels of $\mathrm{E}_{2}$ production induced in granulosa cells cultured in the presence of low doses of pyruvate were similar to those observed under the same conditions in the presence of glucose (Figs 2 and 3).

\section{Lactate production}

Lactate production, by cells cultured in the presence of physiological $(2.1 \mathrm{mM})$ and supra-physiological $(16.7 \mathrm{mM})$ doses of monosaccharide and pyruvate, was determined. There was no significant effect of time in culture on lactate production, so data were pooled across all times (Fig. 4). Culture of granulosa cells in the presence of glucose resulted in levels of lactate production which were two orders of magnitude higher than in the total absence of monosaccharide $(P<0.001)$. There was no significant stimulation of lactate production in the presence of either dose of galactose or pyruvate, whereas the high dose of fructose, but not the low dose, resulted in significant levels of lactate production $(P<0.001)$.

\section{The expression of SLC2A (GLUT) mRNAs}

For SLC2A5 mRNA, a standard curve was successfully constructed using cDNAs from samples of sheep intestine, but no positive signal was detected in cultured granulosa cells. Two further alternate primers sets

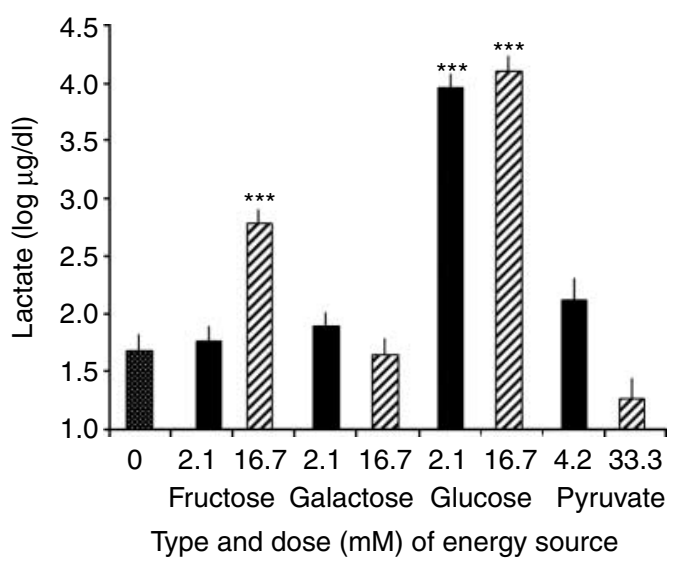

Figure 4 Lactate accumulation in media from granulosa cells from small immature follicles (between 1 and $3 \mathrm{~mm}$ in diameter) cultured in the absence of, or in the presence of, low or high doses of three different monosaccharides and pyruvate. Data have been combined from across different time points. Values are mean \pm S.E.M. Asterisks indicate $P<0.001$ for comparison with zero dose. 
(a)

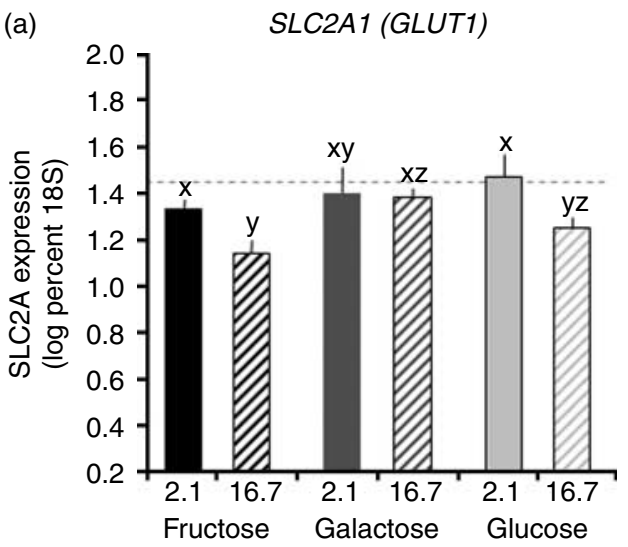

(b)

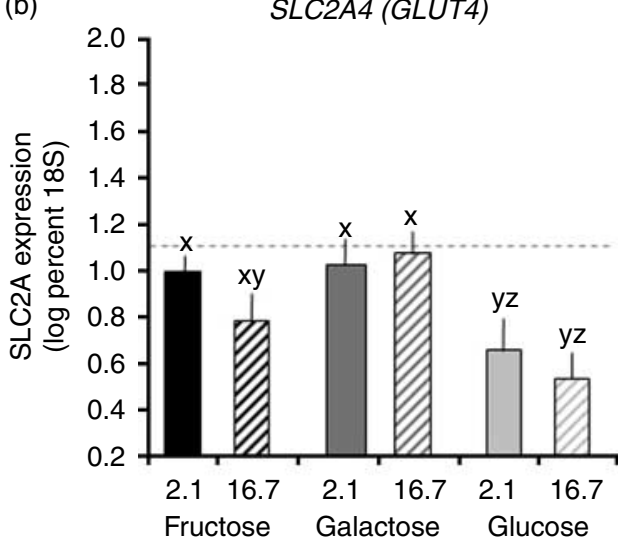

(c)

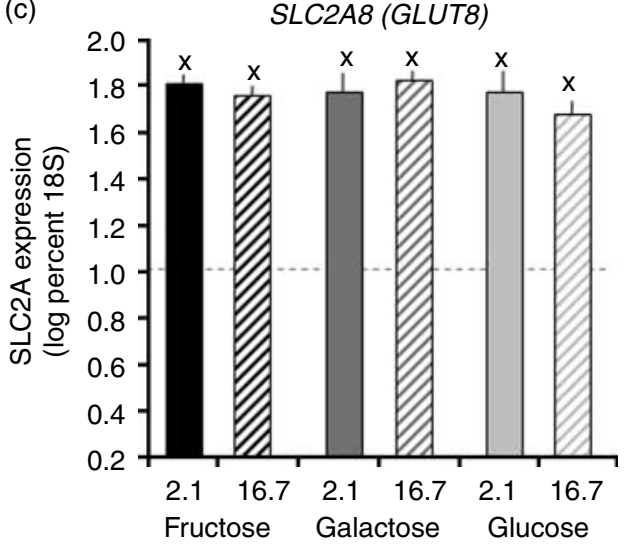

Figure 5 mRNA expression of $S L C 2 A$ in granulosa cells from small immature follicles (between 1 and $3 \mathrm{~mm}$ in diameter) after culture in the presence of low or high doses of three different monosaccharides. Data have been combined from across different time points. Dashed horizontal line represents the level of mRNA expression in freshly isolated cell at time zero. Values are mean \pm s.E.M. of the ratio of SLC2A to $18 \mathrm{~S}$ expression, converted to a percentage and subjected to log transformation. Different letters indicate statistically significant differences $(P<0.05)$.

designed from the ovine or bovine sequence were tested, but again no positive signal for SLC2A5 mRNA was detected in granulosa cells.

Conversely, mRNA expression of SLC2A1, SLC2A4 and $S L C 2 A 8$ was detected in granulosa cells at time zero and in granulosa cells cultured for up to $192 \mathrm{~h}$ in the presence of low and high doses of monosaccharide (Fig. 5). There were no significant effects of time in culture on SLC2A mRNA expression within treatment groups, and these data were, therefore, pooled for further analysis. Both SLC2A1 (Fig. 5a) and SLC2A4 (Fig. 5b) expression exhibited generally similar responses, although there were some differences. Thus, galactose had no effect on SLC2A1 or SLC2A4 expression, whereas higher doses of both fructose and glucose resulted in a depression in both SLC2A1 and SLC2A4 expression, although the effect of high dose fructose on SLC2A4 expression did not reach statistical significance. In addition, SLC2A4 expression was also significantly $(P<0.05)$ suppressed by the low dose of glucose (Fig. 5b). In contrast, dose and type of monosaccharide had no effect on SLC2A8 expression in cultured granulosa cells (Fig. 5c).

\section{Discussion}

The results of this study have shown that while glucose is the preferred energy substrate to support the gonadotrophin-induced differentiation of ovine granulosa cells in vitro, fructose and pyruvate, but not galactose, represent alternative energy sources despite marked differences between these substrates in the way they are metabolised. Furthermore, we have shown that while cultured granulosa cells respond to insulin in a dosedependent manner and express a number of glucose transporters (SLC2A1, SLC2A4 and SLC2A8), expression of both SLC2A1 and SLC2A4 is regulated at a local level by the concentration of glucose and/or fructose.

To our knowledge, this is the first study showing a direct requirement for glucose in the gonadotrophininduced differentiation of ovarian granulosa cells. Glucose is a critical metabolic fuel in mammals, and while most mammals derive their glucose from the diet, ruminants do not. The ruminant is dependent on the biosynthesis of glucose from dietary precursors such as propionic acid, a product of anaerobic fermentation of carbohydrate in the rumen, and from gluconeogenic amino acids absorbed from the small intestine (Scaramuzzi et al. 2006). The ability of granulosa cells to survive under culture conditions in the complete absence of pyruvate or monosaccharide may be explained by the ability of these cells to utilise amino acids such as glutamine in the culture media or cellular glycogen for gluconeogenesis, but further work is needed to test this hypothesis. The requirement for glucose to induce cellular differentiation of granulosa cells shown in this study is consistent with in vivo studies showing that treatment with non-metabolisable 2-deoxy-D-glucose resulted in cessation of oestrous cycles in cattle (McClure et al. 1978) and prevention of the LH surge in sheep (Funston et al. 1995). Furthermore, it has been shown that there is a significant uptake of glucose by the ovary in sheep (Scaramuzzi et al. 2010) 
and cattle (Rabiee et al. 1997). It has been previously shown that significant quantities of lactate are produced by the ovary in vivo (Rabiee et al. 1997), and the results of the present study indicate that the likely source of this lactate is the anaerobic metabolism of glucose by granulosa cells. This idea is consistent with the fact that the membrana granulosa cell layer in ovarian follicles is avascular and that intra-follicular oxygen tensions are very low (Murray et al. 2009).

One surprising aspect of our data was the ability of glucose to support gonadotrophin-induced differentiation of granulosa cells at such low doses. Doses in the physiological range (1.1-2.1 mM; Somchit et al. 2007, Nandi et al. 2008, Scaramuzzi et al. 2010) were as effective as the tenfold higher dose $(16.7 \mathrm{mM})$ commonly found in most commercial culture media. This suggests that in commercial, widely used media, glucose is present in vast excess to that required to provide energy via glycolysis, and therefore may also be exerting an effect on cellular differentiation and function via alternative mechanisms. One of the most widely studied of these alternate pathways is the hexosamine signalling pathway which, via the input of glucose and production of glucosamine-6-phosphate, is able to sense and respond to nutritional fluctuations by altering specific gene expression (Marshall et al. 1991, Obici \& Rossetti 2003, Curi et al. 2005). While the hexosamine pathway has mainly been studied in muscle and fat, it has been shown to be an important pathway in energy metabolism of cumulus-oocyte complexes (Thompson 2006), and genes shown to be responsive to increased glucose via the hexosamine pathway, such as leptin (Wang et al. 1998, McClain et al. 2000), basic fibroblast growth factor (McClain et al. 1992) and transforming growth factor- $\alpha$ (McClain et al. 1992), have been shown to modulate ovarian steroidogenesis (Campbell et al. 1994, Scaramuzzi \& Downing 1995, Spicer \& Francisco 1997, Kendall et al. 2004). In addition, systemic infusion of glucosamine has been shown to stimulate follicular development in a similar manner to that seen following glucose infusion (Munoz-Gutierrez et al. 2002), demonstrating that the hexosamine signalling pathway can induce changes in the ovine ovary and implying glucose may elicit its effects via this pathway. Further work is, therefore, required to confirm whether the hexosamine signalling pathway does have a role in the gonadotrophin-induced differentiation of sheep granulosa cells in vitro.

The current study has also confirmed and extended previous findings (Williams et al. 2001, Nishimoto et al. 2006), showing that ruminant granulosa cells express both the non-insulin-dependent and insulin-dependent glucose transporters, SLC2A1 and SLC2A4 respectively. The levels of both SLC2A1 and SLC2A4 expression did not vary with the differentiative status of granulosa cells, and high levels of SLC2A1 and SLC2A4 mRNA were detected in freshly isolated cells at time zero and for up to $192 \mathrm{~h}$ in cultured cells not exposed to glucose. The down-regulatory effect of glucose on SLC2A1 and SLC2A4 mRNA expression in cultured granulosa cells is consistent with similar inhibitory effects of high glucose reported in the literature (review: Klip et al. (1994)). However, in cultured cells, down-regulation of SLC2A1, but not SLC2A4, expression has most commonly been observed in response to elevated glucose, whereas depression in SLC2A4 protein and mRNA expression has been commonly observed in response to in vivo exposure to glucose in many species (review: Klip et al. (1994)). It, therefore, appears likely that both SLC2A1 and SLC2A4 mRNA expression in sheep granulosa cells is regulated by local mechanisms that respond to differences in the availability of substrate or products of metabolism. The expression of SLC2A4 mRNA by sheep granulosa cells is consistent with the ability of granulosa cells cultured in the presence of glucose to respond to insulin in a dose-dependent manner (Fig. 3). However, the inclusion of insulin in the culture is essential for granulosa cell survival in this serum-free system (Campbell et al. 1996), and at higher doses, insulin interacts with the type 1 IGF receptor and therefore mimics many of the stimulatory effects of IGF1 on granulosa cell differentiation (Campbell et al. 1996). It is, therefore, possible that the stimulatory effect of high levels of insulin in amplifying the differentiative effects of FSH in granulosa cells (Campbell et al. 1996) operates via mechanisms other than through modulation of energy supply (Lopaczynski 1999). This view is supported by the fact that the granulosa cells cultured in the presence of fructose and galactose also responded to the higher doses of insulin.

Once absorbed, fructose can be metabolised by conversion to fructose-6-phosphate by hexokinases and hence enter directly the glycolytic pathway, or it can be converted into fructose-1-phosphate by fructokinase from which the trioses dihydroxyacetone and glyceraldehyde are synthesised before complete metabolism to pyruvate (Zubay 1998). In farm animals, in which fructose is the principle sugar in semen, high levels of SLC2A5 expression are observed in spermatozoa, and fructose is metabolised by hexokinases directly via the glycolytic pathway (Jones \& Connor 2000) with the resultant production of large amounts of lactate (Jones \& Connor 2004). In the current study, we were unable to detect SLC2A5 expression in ovarian granulosa cells, but fructose was capable of supporting relatively high levels of cell survival, the $\mathrm{FSH}$-induced induction of $\mathrm{E}_{2}$ production and the accumulation of significant amounts of lactate when included at high doses. The failure to find SLC2A5 expression in sheep ovarian somatic cells is in agreement with the study of Kol et al. (1997) in the rat ovary, and it is, therefore, likely that granulosa cells may contain other SLC2A capable of transporting fructose. These include SLC2A2, SLC2A7, SLC2A8 and SLC2A11 (Zhao \& Keating 2007). In the present study, we have 
confirmed the finding of Pisani et al. (2008) that SLC2A8 (formerly GLUT8) is expressed by sheep granulosa cells. Expression of SLC2A8 was not affected by exposure to either fructose or galactose, both of which are thought to be preferentially transported by this factor, and this finding is consistent with the current view that SLC2A8 primarily catalyses the transport of sugar through intracellular membranes rather than across the plasma membrane (Schmidt et al. 2009). Although we found that granulosa cells cultured in the presence of fructose were able to respond to insulin in a dose-dependent manner, the fact that SLC2A4 mRNA expression responded differentially to identical doses of glucose and fructose suggests that SLC2A4 was not acting as a major fructose transporter in sheep granulosa cells. In the ruminant, dietary fructose is thought to be rapidly metabolised to glucose in the liver (Luick et al. 1957, Boda 1964), but in sheep, we have observed insulin responses to a fructose challenge which differ in terms of duration and magnitude to identical doses of glucose (Onions et al. 2009), and both direct ovarian and systemic infusions of fructose had stimulatory effects on ovarian androstenedione and $\mathrm{E}_{2}$ secretion (Onions et al. 2009). The current study supports these in vivo findings and shows that fructose may have a direct effect on ovarian function, but more work is required to clarify the physiological basis and mechanism of these effects.

The main products of galactose metabolism are glucose (in the form of glucose-1-phosphate which then enters the glycolytic pathway) and UDP-galactose, which is required for glycoconjugation of proteins and lipids (Forges et al. 2006). In contrast to fructose, a number of SLC2As that transport galactose (GLUT1, GLUT2, GLUT3 and GLUT8) have been reported in the ruminant ovary ((Nishimoto et al. 2006; GLUT1 and GLUT3); (Pisani et al. 2008; GLUT1, GLUT3 and GLUT8); (Williams et al. 2001; GLUT1)). It is, therefore, surprising that galactose was the least well utilised of the sugars tested by the granulosa cells, and it is significant that very little lactate was synthesised in cells cultured in the presence of galactose. This suggests that galactose does not enter glycolysis in granulosa cells, despite the theoretical availability of this pathway. The ovary in rodents and humans has an abundance of the enzymes required to metabolise galactose utilising the Leloir pathway (Liu et al. 2000), but little is known of the patterns of expression of these enzymes in ruminants. The accumulation of galactose or its metabolites is associated with impaired ovarian function in the human, which arises typically because of a deficiency or a mutation of galactose-1-phosphate uridyltransferase, one of the key enzymes required for the metabolism of galactose. The pathogenesis of this ovarian dysfunction is unclear, but in addition to direct toxicity, it includes deficient galactosylation of glycoproteins and glycolipids, induction of apoptosis and modulation of the expression of intra-ovarian growth factors such as growth differentiation factor 9 (Forges et al. 2006). These toxic effects of galactose on ovarian function are consistent with our observed inhibitory effects of high doses of galactose on $\mathrm{FSH}$-induced differentiation of granulosa cells and the fact that direct ovarian infusion of galactose in sheep led to a depression in ovarian $E_{2}$ and androstenedione secretion (Onions et al. 2009). The role of galactose in the ruminant, particularly in relation to possible effects of feeding rations rich in galactose, such as lupins (van Barneveld 1999), on ovarian function is, therefore, a research priority.

As pyruvate is the primary output of the glycolysis of glucose, it was expected that the inclusion of this carboxylate in the culture media would mimic the responses observed with glucose. However, while pyruvate at low equimolar doses supported FSH-induced differentiation of granulosa cells to similar levels as those observed for glucose, in several other respects, the response of the cells differed markedly between these two energy substrates. Thus, higher doses of pyruvate were strongly inhibitory to $E_{2}$ production, whereas high doses of glucose were not. Furthermore, cells cultured in the presence of pyruvate produced negligible quantities of lactate, whereas provision of glucose as a substrate resulted in the accumulation of large amounts of lactate. This latter observation suggests that the granulosa cells were able to metabolise exogenous pyruvate aerobically via the Krebs cycle but that pyruvate derived endogenously by the metabolism of glucose was preferentially shunted to produce lactate. A possible explanation for this unexpected finding may lie in the mechanisms regulating pyruvate transport. Carboxylates such as pyruvate and lactate are transferred across cell membranes by monocarboxylate transporters (MCTs, also known as SLC16As), which currently make up a family of 14 proteins related by sequence homology (Merezhinskaya \& Fishbein 2009). The MCTs classically transport metabolites across plasma membranes, but they may also function in sub-cellular membranes and have different substrate specificities (Merezhinskaya \& Fishbein 2009). Little is known of the actions of these MCTs in the ovary, but their presence would be predicted given that a primary role of MCT1-4 is lactate efflux in cells generating large amounts of lactic acid from anaerobic glycolysis (Merezhinskaya \& Fishbein 2009). Given that pyruvate requires translocation to the mitochondria for aerobic respiration, the presence and differential expression of MCTs in ovarian somatic cells may, therefore, explain the unexpected finding that exogenous and endogenous pyruvate are differentially metabolised by granulosa cells. However, more work is required to confirm this suggestion. Similarly, the depressive effects of high doses of pyruvate on granulosa cell differentiation may be related to changes in the expression of MCTs, but because pyruvate can also be metabolised by numerous alternative pathways, a number of other mechanisms may explain this observation. 
In conclusion, this study has provided clear evidence that glucose, metabolised under anoxic conditions to lactate, is the preferred energy substrate to support the gonadotrophin-induced differentiation of ovine granulosa cells in vitro and that while cultured granulosa cells respond to insulin in a dose-dependent manner, paradoxically, expression of both SLC2A1 and SLC2A4 is inhibited in vitro by high doses of glucose. Furthermore, these data have shown that fructose and pyruvate, but not galactose, are alternative energy substrates for granulosa cell differentiation, but that there are marked differences between these substrates in the way they are metabolised. More work is, therefore, required to elucidate the underlying mechanisms resulting in these differences and to relate the findings of these cell culture studies to the established effects of nutrition on reproductive function in this and other species.

\section{Materials and Methods}

Unless otherwise stated, all reagents were purchased from Sigma-Aldrich. Ovine ovaries were obtained from a commercial abattoir. Small immature follicles between 1 and $3 \mathrm{~mm}$ in diameter were dissected from a number of ovaries to negate any individual animal effects, and granulosa cells were isolated using the procedure described previously for ovine tissues (Campbell et al. 1996). Granulosa cells at a density of 75000 viable cells/well in 96-well flat bottom plates (Nunclon, Nunc) with $250 \mu \mathrm{l}$ of media were used to examine the influence of different monosaccharides on cell proliferation and $E_{2}$ production. Granulosa cells, at an equivalent density of 450000 cells/well in 24-well flat bottom plates (Nunclon, Nunc, Roskilde, Denmark) with $1 \mathrm{ml}$ of media, were used to examine the effect of different monosaccharides on glucose transporter expression. Granulosa cell culture media were supplemented with $1 \mathrm{ng} / \mathrm{ml}$ of FSH (NIDDK-oFSH-20), $1-10 \mathrm{ng} / \mathrm{ml}$ LR3-IGF and varying doses of insulin. These combination of factors have been shown previously to be optimal for induction of $\mathrm{E}_{2}$ production by sheep granulosa cells cultured under serum-free conditions (Campbell et al. 1996). The granulosa cell culture medium was McCoys $5 \mathrm{a}$, which was custom prepared with no glucose or pyruvate (JRH Biosciences Inc., Lenexa, KS, USA and BioConcept, Allschwil, Switzerland) and subsequently supplemented with $0,1.1,2.1,4.2,8.4$ and $16.7 \mathrm{nM}$ of glucose, fructose or galactose. These doses were designed to span the normal physiological range $(1.1-2.1 \mathrm{mM}$; Somchit et al. 2007, Nandi et al. 2008, Scaramuzzi et al. 2010) to a maximum of $16.7 \mathrm{mM}$ that represented the normal rate of glucose supplementation in commercial preparations of these media. Similarly, media were supplemented with pyruvate across a similar equimolar dose range to a maximum of $33 \mathrm{mM}$. The McCoys $5 \mathrm{a}$ was also supplemented with sodium bicarbonate $(2.2 \mathrm{mg} / \mathrm{ml})$, HEPES $(15 \mathrm{mM})$, BSA $(1 \mathrm{mg} / \mathrm{ml})$, Penstrep $(100 \mathrm{U} / \mathrm{ml}$ penicillin and $0.1 \mathrm{mg} / \mathrm{ml}$ streptomycin), L-glutamine $(0.365 \mathrm{mg} / \mathrm{ml})$, transferrin $(5 \mu \mathrm{g} / \mathrm{ml})$ and selenium $(0.1 \mu \mathrm{g} / \mathrm{ml})$.

For 96-well plate cultures, each dose of monosaccharide or pyruvate was replicated in quadruplicate, and cultures were maintained for $192 \mathrm{~h}$ with $175 \mu \mathrm{l}(70 \%)$ of the media exchanged every $48 \mathrm{~h}$ with equivalent fresh media. Spent media were retained, stored at $-20{ }^{\circ} \mathrm{C}$, for subsequent analysis for $E_{2}$ concentrations. The number of viable cells was estimated using neutral red staining at the end of the culture (Campbell et al. 1996). Steroid production per cell was calculated for the final time point. Each experiment was repeated at least three times.

For 24-well plate cultures, physiological $(2.1 \mathrm{mM} \mathrm{mg} / \mathrm{ml})$ and superphysiological $(16.7 \mathrm{mM})$ doses of each monosaccharide were replicated in duplicate per treatment per time point, and cultures were maintained for up to $192 \mathrm{~h}$ with $700 \mu \mathrm{l}$ $(70 \%)$ of the media being exchanged every $48 \mathrm{~h}$ with equivalent fresh media. Cell lysates for molecular analysis were collected at each time point and stored frozen in RTL buffer with $1 \% \beta$-mercaptoethanol prior to analysis. Spent media were retained, stored at $-20^{\circ} \mathrm{C}$, for subsequent analysis of $E_{2}$ concentrations. Each experiment was repeated at least three times.

Concentrations of $E_{2}$ in unextracted culture media were determined using a previously described RIA (Campbell et al. 1996). The sensitivity of the assay was $1.4 \mathrm{pg} / \mathrm{ml}$. The intra- and inter-assay coefficients of variation (CV) were $<10 \%$.

Concentrations of lactate in the culture media were determined using a commercial enzymatic assay kit for L-lactate (Randox, Belfast, Co., Antrim, UK) and a clinical

Table 1 Details of quantitative PCR primers and PCR conditions for semi-quantification of SLC2A (GLUT) expression levels in ovine granulosa cells cultured in the presence of different monosaccharides.

\begin{tabular}{|c|c|c|c|}
\hline SLC2A & Primers & PCR conditions & References \\
\hline SLC2A1 & $\begin{array}{l}\text { Sense: 5'-TTAACCGCAACGAGGAGAAC-3' } \\
\text { Antisense: 5'-AACAGCTCCAGGATGGTGAC-3' }\end{array}$ & $\begin{array}{l}95^{\circ} \mathrm{C} \text { for } 10 \mathrm{~min}, 95^{\circ} \mathrm{C} \text { for } 20 \mathrm{~s}, 59^{\circ} \mathrm{C} \text { for } 30 \mathrm{~s} \\
\text { and } 72{ }^{\circ} \mathrm{C} \text { for } 1 \text { min. } 40 \text { cycles }\end{array}$ & $\begin{array}{l}\text { Accession no. } \\
\text { U89029 }\end{array}$ \\
\hline SLC2A4 & $\begin{array}{l}\text { Sense: 5'-GGAGCTGGTGTGGTCACACA-3' } \\
\text { Antisense 5'-GGAGCAGAGCCACAGTCATCA-3' }\end{array}$ & $\begin{array}{l}94{ }^{\circ} \mathrm{C} \text { for } 15 \mathrm{~min}, 94{ }^{\circ} \mathrm{C} \text { for } 15 \mathrm{~s}, 60^{\circ} \mathrm{C} \text { for } 20 \mathrm{~s} \\
\text { and } 72{ }^{\circ} \mathrm{C} \text { for } 30 \mathrm{~s} .40 \text { cycles }\end{array}$ & $\begin{array}{l}\text { Benomar et al. } \\
\text { (2006) }\end{array}$ \\
\hline SLC2A5 & $\begin{array}{l}\text { Sense: 5'-AGTCATCTCCATCATCGTCCT-3' } \\
\text { Antisense: 5'-GTACCCGCCACCATGTAGGCAG-3' }\end{array}$ & $\begin{array}{l}94^{\circ} \mathrm{C} \text { for } 10 \min , 94^{\circ} \mathrm{C} \text { for } 15 \mathrm{~s}, 58^{\circ} \mathrm{C} \text { for } 30 \mathrm{~s} \\
\text { and } 72{ }^{\circ} \mathrm{C} \text { for } 30 \mathrm{~s} .40 \text { cycles }\end{array}$ & $\begin{array}{l}\text { Rizos et al. } \\
\quad(2004)\end{array}$ \\
\hline SLC2A8 & $\begin{array}{l}\text { Sense: 5'-CTGGCATCTACAAGCССTTC-3' } \\
\text { Antisense: 5'-TGAACTTGGCСТCСTCAAAG-3' }\end{array}$ & $\begin{array}{l}95^{\circ} \mathrm{C} \text { for } 10 \mathrm{~min}, 95^{\circ} \mathrm{C} \text { for } 20 \mathrm{~s}, 59^{\circ} \mathrm{C} \text { for } 30 \mathrm{~s} \\
\text { and } 72{ }^{\circ} \mathrm{C} \text { for } 1 \text { min. } 40 \text { cycles }\end{array}$ & $\begin{array}{l}\text { Accession no. } \\
\text { AF } 495799\end{array}$ \\
\hline
\end{tabular}


chemistry autoanalyser (RX Imola, Randox, Belfast, Co.), run with sample volumes increased from 2 to $20 \mu \mathrm{l}$ to increase sensitivity. The sensitivity of the assay was $0.043 \mathrm{mM}$. The intraand inter-assay CV were $<1 \%$.

\section{Solute transporter (GLUT) mRNA expression}

First-strand cDNA libraries were synthesised using the IT 1st strand synthesis kit (ABgene, Epsom, Surrey, UK), and utilising total RNA extracted from ovine granulosa cells using the RNeasy mini kit (Qiagen). These were semi-quantified by realtime PCR using the 7500 fast real-time PCR system (Applied Biosystems, Warrington, UK) with arbitrary SLC2A expression levels being normalised against starting amount differences using a $18 \mathrm{~S}$ endogenous control. Samples were amplified in triplicate for determination of levels of expression of SLC2A1, SLC2A4, SLC2A5 and SLC2A8 utilising the primers and PCR conditions detailed in Table 1.

\section{Data analysis}

Each experiment was repeated at least three times, and the significance of treatment effects was determined by ANOVA utilising either SPSS (SPSS UK Ltd, Surrey, UK) or Systat (SSI, San Jose, CA, USA) statistical packages. The primary end points determined were hormone production per $48 \mathrm{~h}$ time point (48, 96, 144 and $192 \mathrm{~h}$ ) expressed as concentration after correction for the residual amount of media left in the wells when the media were changed, the number of viable cells at the end of culture and mass of hormone produced per 1000 cells in $48 \mathrm{~h}$. For clarity, only responses to the physiological $(2.1 \mathrm{mM})$ and superphysiological $(16.7 \mathrm{mM})$ doses of monosaccharide have been presented for illustrative purposes in Fig. 1, whereas the results of the main effect analysis presented in the text utilised the complete dose-response. Data presented are least-squares means and S.E.M. The normality and homogeneity of variances of the data were determined using appropriate tests and data transformed as required.

\section{Declaration of interest}

The authors declare that there is no conflict of interest that could be perceived as prejudicing the impartiality of the research reported.

\section{Funding}

This work was supported by the BBSRC.

\section{Acknowledgements}

We thank Mrs Catherine Pincott-Allen for technical assistance in the conduct of the immunoassays. We thank the National Institute of Arthritis, Diabetes and Digestive and Kidney Diseases (Torrence, CA, USA) for purified ovine gonadotrophins.

\section{References}

van Barneveld RJ 1999 Understanding the nutritional chemistry of lupin (Lupinus spp.) seed to improve livestock production efficiency. Nutrition Research Reviews 12 203-230. (doi:10.1079/095442299108728938)

Benomar Y, Naour N, Aubourg A, Bailleux V, Gertler A, Djiane J, GuerreMillo M \& Taouis M 2006 Insulin and leptin induce Glut4 plasma membrane translocation and glucose uptake in a human neuronal cell line by a phosphatidylinositol 3-kinase-dependent mechanism. Endocrinology 147 2550-2556. (doi:10.1210/en.2005-1464)

Boda JM 1964 Effect of fast +hexose injection on serum insulin concentrations of sheep. American Journal of Physiology 206 419-424.

Burant CF, Takeda J, Brotlaroche E, Bell GI \& Davidson NO 1992 Fructose transporter in human spermatozoa and small intestine is GLUT5. Journal of Biological Chemistry 267 14523-14526.

Campbell B, Gordon B \& Scaramuzzi R 1994 The effect of ovarian arterial infusion of transforming growth factor alpha on ovarian hormone secretion by ewe with an autotransplanted ovary. Journal of Endocrinology 143 13-24. (doi:10.1677/joe.0.1430013)

Campbell B, Scaramuzzi R \& Webb R 1996 Induction and maintenance of oestradiol and immuno-reactive inhibin production with $\mathrm{FSH}$ by ovine granulosa cells cultured in serum free media. Journal of Reproduction and Fertility 106 7-16. (doi:10.1530/jrf.0.1060007)

Curi R, Lagranha CJ, Doi SQ, Sellitti DF, Procopio J, Pithon-Curi TC, Corless M \& Newsholme P 2005 Molecular mechanisms of glutamine action. Journal of Cellular Physiology 204 392-401. (doi:10.1002/jcp.20339)

Curry DL 1989 Effects of mannose and fructose on the synthesis and secretion of insulin. Pancreas 4 2-9. (doi:10.1097/00006676-198902000-00002)

Daniels LB, Perkins JL, Krieder D, Tugwell D \& Carpente D 1974 Blood glucose and fructose in newborn ruminant. Journal of Dairy Science $\mathbf{5 7}$ 1196-1200. (doi:10.3168/jds.S0022-0302(74)85036-8)

Davis SR, Smith JF \& Gluckman PD 1990 Effects of growth hormone injections on ovulation rate in ewes. Reproduction, Fertility, and Development 2 173-178. (doi:10.1071/RD9900173)

Downing J, Joss J \& Scaramuzzi R 1999 The effect of a direct arterial infusion of insulin and glucose on the ovarian secretion rates of androstenedione and oestradiol in ewes with an autotransplanted ovary. Journal of Endocrinology 163 531-541. (doi:10.1677/joe.0.1630531)

Elliott SS, Keim NL, Stern JS, Teff K \& Havel PJ 2002 Fructose, weight gain, and the insulin resistance syndrome. American Journal of Clinical Nutrition 76 911-922.

Forges T, Monnier-Barbarino P, Leheup B \& Jouvet P 2006 Pathophysiology of impaired ovarian function in galactosaemia. Human Reproduction Update 12 573-584. (doi:10.1093/humupd/dml031)

Funston RN, Roberts AJ, Hixon DL, Hallford DM, Sanson DW \& Moss GE 1995 Effect of acute glucose antagonism on hypophyseal hormones and concentrations of insulin-like growth factor (IGF)-I and IGF-binding proteins in serum, anterior pituitary, and hypothalamus of ewes. Biology of Reproduction 52 1179-1186. (doi:10.1095/biolreprod52.5.1179)

Havel PJ 1997 Glucose but not fructose infusion increases circulating leptin in proportion to adipose stores in rhesus monkeys. Experimental and Clinical Endocrinology and Diabetes 105 37-38.

Heidenreich RA, Mallee J, Rogers S \& Segal S 1993 Developmental and tissue-specific modulation of rat galactose-1-phosphate uridyl transferase steady-state messenger RNA-and specific activity levels. Pediatric Research 34 416-419. (doi:10.1203/00006450-199310000-00006)

Jolly PD, McDougall S, Fitzpatrick LA, Macmillan KL \& Entwistle KW 1995 Physiological effects of undernutrition on postpartum anestrus in cows. Journal of Reproduction and Fertility Supplement 49 477-492.

Jones AR \& Connor DE 2000 Fructose metabolism by mature boar spermatozoa. Reproduction, Fertility, and Development 12 355-359. (doi:10.1071/RD00116)

Jones AR \& Connor DE 2004 Control of glycolysis in mature boar spermatozoa: effect of $\mathrm{pH}$ in vitro. Reproduction, Fertility, and Development 16 319-324. (doi:10.1071/RD02103)

Jozwik M, Teng C \& Battaglia FC 2007 Concentrations of monosaccharides and their amino and alcohol derivatives in human preovulatory follicular fluid. Molecular Human Reproduction 13 791-796. (doi:10.1093/ molehr/gam060)

Katz MG \& Vollenhoven B 2000 The reproductive endocrine consequences of anorexia nervosa. British Journal of Obstetrics and Gynaecology $\mathbf{1 0 7}$ 707-713. (doi:10.1111/j.1471-0528.2000.tb13329.x) 
Kendall NR, Gutierrez CG, Scaramuzzi RJ, Baird DT, Webb R \& Campbell BK 2004 Direct in vivo effects of leptin on ovarian steroidogenesis in sheep. Reproduction 128 757-765. (doi:10.1530/rep.1.00256)

Klip A, Tsakiridis T, Marette A \& Ortiz PA 1994 Regulation of expression of glucose transporters by glucose: a review of studies in vivo and in cell cultures. FASEB Journal 8 43-53.

Knight TW, Oldham CM \& Lindsay DR 1975 Studies in ovine infertility in agricultural regions in Western Australia - influence of a supplement of lupins (Lupinus augustifolius cv. Uniwhite) at joining on reproductive performance of ewes. Australian Journal of Agricultural Research 26 567-575. (doi:10.1071/AR9750567)

Kol S, Ben-Shlomo I, Ruutiainen K, Ando M, Davies-Hill TM, Rohan RM, Simpson IA \& Adashi EY 1997 The midcycle increase in ovarian glucose uptake is associated with enhanced expression of glucose transporter 3. Possible role for interleukin-1, a putative intermediary in the ovulatory process. Journal of Clinical Investigation 99 2274-2283. (doi:10.1172/JCI119403)

Liu GT, Hale GE \& Hughes CL 2000 Galactose metabolism and ovarian toxicity. Reproductive Toxicology 14 377-384. (doi:10.1016/S08906238(00)00096-4)

Lopaczynski W1999 Differential regulation of signaling pathways for insulin and insulin-like growth factor I. Acta Biochimica Polonica 46 51-60.

Luick JR, Kleiber M, Lucas JM \& Rogers TA 1957 Fructose metabolism in dairy cows. American Journal of Physiology 191 90-94.

Marshall S, Garvey WT \& Traxinger RR 1991 New insights into the metabolic regulation of insulin action and insulin resistance: role of glucose and amino acids. FASEB Journal 5 3031-3036.

McClain DA, Paterson AJ, Roos MD, Wei XP \& Kudlow JE 1992 Glucose and glucosamine regulate growth-factor gene expression in vascular smooth muscle cells. PNAS 89 8150-8154. (doi:10.1073/pnas.89.17.8150)

McClain DA, Alexander T, Cooksey RC \& Considine RV 2000 Hexosamines stimulate leptin production in transgenic mice. Endocrinology $\mathbf{1 4 1}$ 1999-2002. (doi:10.1210/en.141.6.1999)

McClure TJ, Nancarrow CD \& Radford HM 1978 The effect of 2-deoxy-Dglucose on ovarian function of cattle. Australian Journal of Biological Sciences 31 183-186.

McShane TM, Wise PM \& Jennes L 1994 Neuropeptide-Y neurons projectioning to the medial septum-diagonal band do not have access to fenestrated capillaries in the rat brain. Molecular and Cellular Neurosciences 5 459-465. (doi:10.1006/mcne.1994.1056)

Merezhinskaya N \& Fishbein WN 2009 Monocarboxylate transporters: past, present, and future. Histology and Histopathology 24 243-264.

Munoz-Gutierrez M, Blache D, Martin GB \& Scaramuzzi RJ 2002 Folliculogenesis and ovarian expression of mRNA encoding aromatase in anoestrous sheep after 5 days of glucose or glucosamine infusion or supplementary lupin feeding. Reproduction 124 721-731. (doi:10.1530/rep.0.1240721)

Munoz-Gutierrez M, Blache D, Martin GB \& Scaramuzzi RJ 2004 Ovarian follicular expression of mRNA encoding the type I IGF receptor and IGFbinding protein-2 in sheep following five days of nutritional supplementation with glucose, glucosamine or lupins. Reproduction $\mathbf{1 2 8}$ 747-756. (doi:10.1530/rep.1.00439)

Munoz-Gutierrez M, Findlay PA, Adam CL, Wax G, Campbell BK, Kendall NR, Khalid M, Forsberg M \& Scaramuzzi RJ 2005 The ovarian expression of mRNAs for aromatase, IGF-I receptor, IGF-binding protein$2,-4$ and -5 , leptin and leptin receptor in cycling ewes after three days of leptin infusion. Reproduction 130 869-881. (doi:10.1530/rep.1.00557)

Murray JF, Giles RM, Carter ND \& Robinson SP 2009 The antrums of ovine ovarian preovulatory follicles are severely hypoxic. Society for Reproduction and Fertility Annual Conference, 12-14th July, pp 38.

Nandi S, Kumar VG, Manjunatha BM, Ramesh HS \& Gupta PSP 2008 Follicular fluid concentrations of glucose, lactate and pyruvate in buffalo and sheep, and their effects on cultured oocytes, granulosa and cumulus cells. Theriogenology 69 186-196. (doi:10.1016/j.theriogenology.2007.08.036)

Nishimoto H, Matsutani R, Yamamoto S, Takahashi T, Hayashi KG, Miyamoto A, Hamano S \& Tetsuka M 2006 Gene expression of glucose transporter (GLUT) 1, 3 and 4 in bovine follicle and corpus luteum. Journal of Endocrinology 188 111-119. (doi:10.1677/joe.1.06210)

Obici S \& Rossetti L 2003 Minireview: nutrient sensing and the regulation of insulin action and energy balance. Endocrinology 144 5172-5178. (doi:10.1210/en.2003-0999)

Onions V, Kendall N, Scaramuzzi R \& Campbell BK 2009 The effect of systemic and arterial infusion of glucose, galactose and fructose on ovine ovarian function. Fertility 40 (7-9 January).
Peluso JJ, Downey MC \& Gruenberg ML 1984 Role of LH pulse amplitude in controlling rat ovarian oestradiol-17 beta secretion in vitro. Journal of Reproduction and Fertility 71 107-112. (doi:10.1530/jrf.0.0710107)

Pisani LF, Antonini S, Pocar P, Ferrari S, Brevini TA, Rhind SM \& Gandolfi F 2008 Effects of pre-mating nutrition on mRNA levels of developmentally relevant genes in sheep oocytes and granulosa cells. Reproduction 136 303-312. (doi:10.1530/REP-07-0394)

Rabiee AR, Lean IJ, Gooden JM, Miller BG \& Scaramuzzi RJ 1997 An evaluation of transovarian uptake of metabolites using arterio-venous difference methods in dairy cattle. Animal Reproduction Science $\mathbf{4 8}$ 9-25. (doi:10.1016/S0378-4320(97)00032-8)

Rizos D, Gutierrez-Adan A, Moreira P, O'Meara C, Fair T, Evans ACO, Boland MP \& Lonergan P 2004 Species-related differences in blastocyst quality are associated with differences in relative mRNA transcription. Molecular Reproduction and Development 69 381-386. (doi:10.1002/mrd.20133)

Scaramuzzi RJ \& Downing JA 1995 The in vivo effects of fibroblast growth factor and epidermal growth factor on the secretion of estradiol, androstenedione and progesterone by the autotransplanted ovary in the ewe. Journal of Endocrinology 146 301-311. (doi:10.1677/joe.0.1460301)

Scaramuzzi RJ, Campbell BK, Downing JA, Kendall NR, Khalid M, MunozGutierrez M \& Somchit A 2006 A review of the effects of supplementary nutrition in the ewe on the concentrations of reproductive and metabolic hormones and the mechanisms that regulate folliculogenesis and ovulation rate. Reproduction, Nutrition, Development 46 339-354. (doi:10.1051/rnd:2006016)

Scaramuzzi RJ, Campbell BK, Souza CJH \& Baird DT 2010 Glucose uptake and lactate production by the autotransplanted ovary of the ewe during the luteal and follicular phases of the oestrous cycle. Theriogenology 73 1061-1067. (doi:10.1016/j.theriogenology.2010.01.005)

Schmidt S, Joost HG \& Schurmann A 2009 GLUT8, the enigmatic intracellular hexose transporter. American Journal of Physiology. Endocrinology and Metabolism 296 E614-E618. (doi:10.1152/ajpendo.91019.2008)

Somchit A, Campbell BK, Khalid M, Kendall NR \& Scaramuzzi RJ 2007 The effect of short-term nutritional supplementation of ewes with lupin grain (Lupinus luteus), during the luteal phase of the estrous cycle on the number of ovarian follicles and the concentrations of hormones and glucose in plasma and follicular fluid. Theriogenology 68 1037-1046. (doi:10.1016/j.theriogenology.2007.08.001)

Spicer LJ \& Francisco CC 1997 The adipose obese gene product, leptin: evidence of a direct inhibitory role in ovarian function. Endocrinology 138 3374-3379. (doi:10.1210/en.138.8.3374)

Teff KL, Elliott SS, Tschop M, Kieffer TJ, Rader D, Heiman M, Townsend RR, Keim NL, D'Alessio D \& Havel PJ 2004 Dietary fructose reduces circulating insulin and leptin, attenuates postprandial suppression of ghrelin, and increases triglycerides in women. Journal of Clinical Endocrinology and Metabolism 89 2963-2972. (doi:10.1210/jc.2003-031855)

Thompson JG 2006 The impact of nutrition of the cumulus oocyte complex and embryo on subsequent development in ruminants. Journal of Reproduction and Development 52 169-175.

Wang JL, Liu R, Hawkins M, Barzilai N \& Rossetti L 1998 A nutrient-sensing pathway regulates leptin gene expression in muscle and fat. Nature 393 684-688. (doi:10.1038/31474)

Webb R \& Campbell BK 2007 Development of the dominant follicle: mechanisms of selection and maintenance of oocyte quality. Society of Reproduction and Fertility Supplement 64 141-163.

Williams SA, Blache D, Martin GB, Foot R, Blackberry MA \& Scaramuzzi RJ 2001 Effect of nutritional supplementation on quantities of glucose transporters 1 and 4 in sheep granulosa and theca cells. Reproduction 122 947-956. (doi:10.1530/rep.0.1220947)

Zhao FQ \& Keating AF 2007 Functional properties and genomics of glucose transporters. Current Genomics 8 113-128. (doi:10.2174/138920207780368187)

Zubay G 1998 Glycolysis, gluconeogenesis and the pentose phosphate pathway. In Biochemistry, 4th edn, pp 293-323. Ed. G Zubay. Chicago: Wm. C. Brown Publishers.

Received 19 March 2010

First decision 20 April 2010

Revised manuscript received 1 July 2010

Accepted 15 July 2010 